\title{
Front Matter: Volume 6602
}

, "Front Matter: Volume 6602," Proc. SPIE 6602, Noise and Fluctuations in Biological, Biophysical, and Biomedical Systems, 660201 (21 June 2007); doi: 10.1117/12.748437

Event: SPIE Fourth International Symposium on Fluctuations and Noise, SPIE. 2007, Florence, Italy 


\section{PROCEEDINGS OF SPIE}

\section{Noise and Fluctuations in Biological, Biophysical, and Biomedical Systems}

Sergey M. Bezrukov

Editor

21-23 May 2007

Florence, Italy

Sponsored and Published by

SPIE

Cooperating Organizations

EOS-European Optical Society (Germany)

SIOF (Italy)

SPIE Europe

Volume 6602 
The papers included in this volume were part of the technical conference cited on the cover and title page. Papers were selected and subject to review by the editors and conference program committee. Some conference presentations may not be available for publication. The papers published in these proceedings reflect the work and thoughts of the authors and are published herein as submitted. The publisher is not responsible for the validity of the information or for any outcomes resulting from reliance thereon.

Please use the following format to cite material from this book:

Author(s), "Title of Paper," in Noise and Fluctuations in Biological, Biophysical, and Biomedical Systems, edited by Sergey M. Bezrukov, Proceedings of SPIE Vol. 6602 (SPIE, Bellingham, WA, 2007) Article CID Number.

ISSN 0277-786X

ISBN 9780819467393

Published by

SPIE

P.O. Box 10, Bellingham, Washington 98227-0010 USA

Telephone +1 3606763290 (Pacific Time) · Fax +1 3606471445

SPIE.org

Copyright (c) 2007, Society of Photo-Optical Instrumentation Engineers

Copying of material in this book for internal or personal use, or for the internal or personal use of specific clients, beyond the fair use provisions granted by the U.S. Copyright Law is authorized by SPIE subject to payment of copying fees. The Transactional Reporting Service base fee for this volume is $\$ 18.00$ per article (or portion thereof), which should be paid directly to the Copyright Clearance Center (CCC), 222 Rosewood Drive, Danvers, MA 01923. Payment may also be made electronically through CCC Online at copyright.com. Other copying for republication, resale, advertising or promotion, or any form of systematic or multiple reproduction of any material in this book is prohibited except with permission in writing from the publisher. The CCC fee code is $0277-786 \mathrm{X} / 07 / \$ 18.00$.

Printed in the United States of America.

Publication of record for individual papers is online in the SPIE Digital Library.

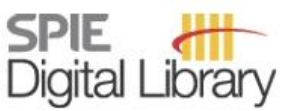

SPIEDigitalLibrary.org

Paper Numbering: Proceedings of SPIE follow an e-First publication model, with papers published first online and then in print and on CD-ROM. Papers are published as they are submitted and meet publication criteria. A unique, consistent, permanent citation identifier (CID) number is assigned to each article at the time of the first publication. Utilization of CIDs allows articles to be fully citable as soon they are published online, and connects the same identifier to all online, print, and electronic versions of the publication. SPIE uses a six-digit CID article numbering system in which:

- The first four digits correspond to the SPIE volume number.

- The last two digits indicate publication order within the volume using a Base 36 numbering system employing both numerals and letters. These two-number sets start with $00,01,02,03,04,05$, 06, 07, 08, 09, OA, OB ... 0Z, followed by 10-1Z, 20-2Z, etc.

The CID number appears on each page of the manuscript. The complete citation is used on the first page, and an abbreviated version on subsequent pages. Numbers in the index correspond to the last two digits of the six-digit CID number. 


\section{Contents}

vii Conference Committee

ix Origins of randomness in statistical and quantum mechanics (Plenary Paper) [6600-500] M. B. Weissman, Univ. of Illinois at Urbana-Champaign (USA)

xix Thermal noise informatics: totally secure communication via a wire, zero-power communication, and thermal noise driven computing (Plenary Paper) [6600-501] L. B. Kish, Texas A\&M Univ. (USA); R. Mingesz, Z. Gingl, Univ. of Szeged (Hungary)

\section{SINGLE MOLECULES}

660206 A new model for myosin dimeric motors incorporating Brownian ratchet and powerstroke mechanisms (Invited Paper) [6602-02]

B. Geislinger, R. Kawai, Univ. of Alabama at Birmingham (USA)

660208 Understanding the role of thermal fluctuations in DNA looping (Invited Paper) [6602-04] D. P. Wilson, T. Lillian, Univ. of Michigan (USA); S. Goyal, Univ. of Michigan (USA) and Woods Hole Oceanographic Institute (USA); A. V. Tkachenko, N. C. Perkins, J.-C. Meiners, Univ. of Michigan (USA)

660209 Computational characterization of the mutation impact on domain C5 of Myosin Binding Protein C [6602-05]

C. Guardiani, Ctr. Interdipartimentale per lo Studio delle Dinamiche Complesse (Italy);

F. Cecconi, Istituto die Sistemi Complessi ISC-CNR (Italy); R. Livi, Univ. di Firenze (Italy)

\section{ION CHANNELS AND PUMPS}

6602 OB Analytical study of a flashing molecular pump (Invited Paper) [6602-07]

J. M. Sancho, A. Gomez-Marin, Univ. de Barcelona (Spain)

6602 OC Effect of noise on a particle moving in a periodic potential (Invited Paper) [6602-08] M. Gitterman, Bar-llan Univ. (Israel)

6602 OD On selectivity and gating of ionic channels (Invited Paper) [6602-09]

D. G. Luchinsky, Lancaster Univ. (United Kingdom) and Ames Research Ctr. (USA);

R. Tindjong, P. V. E. McClintock, Lancaster Univ. (United Kingdom); I. Kaufman, The Russian Research Institute for Metrological Service (Russia); R. S. Eisenberg, Rush Medical College (USA)

6602 OE Self-consistent analytic solution for the current and access resistance in open ionic channels [6602-10]

D. G. Luchinsky, Lancaster Univ. (United Kingdom) and Ames Research Ctr. (USA);

R. Tindjong, P. V. E. McClintock, Lancaster Univ. (United Kingdom); I. Kaufman, The Russian Research Institute for Metrological Service (Russia); R. S. Eisenberg, Rush Medical College (USA) 
6602 OF Surprising features of particle dynamics in channel-facilitated transport [6602-11]

A. M. Berezhkovskii, S. M. Bezrukov, National Institutes of Health (USA)

\section{SENSORY SYSTEMS}

$660206 \quad$ Fluctuations in speech (Invited Paper) [6602-12]

S. Umesh, Indian Institute of Technology (India); L. Cohen, City Univ. of New York (USA);

D. Nelson, U.S. Dept. of Defense (USA)

$6602 \mathrm{OH}$ A hierarchy of phase transitions in optimal neuronal coding: from binary to $M$-ary discrete optimal codes [6602-13]

A. Nikitin, N. G. Stocks, Univ. of Warwick (United Kingdom); R. P. Morse, Univ. of Aston

(United Kingdom)

\section{SIGNAL ANALYSIS}

6602 ol Liposome characterization with fluorescence cumulant analysis [6602-14]

J. E. Reiner, A. Jahn, L. E. Locascio, M. Gaitan, J. J. Kasianowicz, National Institute of

Standards and Technology (USA)

NETWORKS, CELLS, POPULATION DYNAMICS I

6602 0J Stochastic trigger for clathrin-coated vesicle biogenesis (Keynote Paper) [6602-15]

R. Nossal, National Institutes of Health (USA)

$66020 \mathrm{M}$ Mechanism of intracellular $\mathrm{Ca}^{2+}$ oscillations and interspike interval distributions (Invited Paper) [6602-18]

M. Falcke, Hahn Meitner Institut (Germany)

NETWORKS, CELLS, POPULATION DYNAMICS II

660200 White noise and synchronization shaping the age structure of the human population [6602-20]

S. Cebrat, P. Biecek, K. Bonkowska, M. Kula, Wrocław Univ. (Poland)

6602 OP Pandemics and immune memory in the noisy Penna model [6602-21]

S. Cebrat, K. Bonkowska, P. Biecek, Wrocław Univ. (Poland)

NOISE EFFECTS AND STOCHASTIC RESONANCE

$66020 Q$ Coherence resonance in an autapse neuron model with time delay (Invited Paper)

[6602-22]

G. C. Sethia, Institute for Plasma Research (India); J. Kurths, Univ. of Potsdam (Germany);

A. Sen, Institute for Plasma Research (India) 
6602 OR Optimal coding of a random stimulus by a population of parallel neuron models (Invited Paper) [6602-23]

M. D. McDonnell, The Univ. of Adelaide (Australia); N. G. Stocks, The Univ. of Warwick

(United Kingdom); D. Abbott, The Univ. of Adelaide (Australia)

6602 OS Pooling networks for a discrimination task: noise-enhanced detection (Invited Paper) [6602-24]

P.-O. Amblard, S. Zozor, GIPSA-lab, CNRS (France); M. D. McDonnell, The Univ. of Adelaide (Australia); N. G. Stocks, The Univ. of Warwick (United Kingdom)

6602 OT Endogenous neural noise and stochastic resonance (Invited Paper) [6602-25]

L. Emberson, Cornell Univ. (USA); K. Kitajo, RIKEN Brain Science Institute (Japan); L. M. Ward, Univ. of British Columbia (Canada)

6602 OU Stochastic beamforming for cochlear implant coding (Invited Paper) [6602-26]

R. P. Morse, S. D. Holmes, Aston Univ. (United Kingdom); B. Shulgin, A. Nikitin, N. G. Stocks, Univ. of Warwick (United Kingdom)

$66020 \mathrm{~V}$ Fluctuation in the retina: noise-enhanced processing via random sampling and microsaccades? [6602-27]

S. Zozor, P.-O. Amblard, C. Duchêne, GIPSA-Lab., CNRS (France)

\section{CARDIOVASCULAR SYSTEMS I}

$6602 \mathrm{OW}$ On some problems encountered in inference of causality from time series (Invited Paper) [6602-29]

M. Paluš, Institute of Computer Science (Czech Republic)

$66020 \mathrm{X}$ The cardiorespiratory interaction: a nonlinear stochastic model and its synchronization properties (Invited Paper) [6602-30]

A. Bahraminasab, D. Kenwright, A. Stefanovska, P. V. E. McClintock, Lancaster Univ. (United Kingdom)

6602 OY Fluctuations in a coupled-oscillator model of the cardiovascular system (Invited Paper) [6602-31]

J. A. González, Venezuela Institute for Scientific Research (Venezuela); J. J. Suárez-Vargas,

A. Stefanovska, P. V. E. McClintock, Lancaster Univ. (United Kingdom)

\section{CARDIOVASCULAR SYSTEMS II}

$66020 Z$ A simple model for 1/f spectra in heart rate variability (Invited Paper) [6602-32] J. P. Gleeson, Univ. College Cork (Ireland); A. Stefanovska, Lancaster Univ. (United Kingdom)

660210 Phenomenological analysis of medical time series with regular and stochastic components [6602-33]

S. F. Timashev, Karpov Institute of Physical Chemistry (Russia); Y. S. Polyakov, USPolyResearch (USA) 
660211 Noisy unmaskers of multistability of periodic rhythms in a model of the ventricular cardiac action potential [6602-34]

E. Surovyatkina, R. Egorchenkov, Space Research Institute (Russia); G. Ivanov, Moscow Medical Academy (Russia)

660213 Suppression of global oscillations via time-delayed feedback in a net of neural elements [6602-47]

M. Gassel, E. Glatt, F. Kaiser, Darmstadt Univ. of Technology (Germany)

BRAIN AND NEURONAL NETWORKS

660214 Complexity, information loss, and model building: from neuro- to cognitive dynamics (Invited Paper) [6602-36]

F. T. Arecchi, Univ. di Firenze (Italy)

660215 Living ordered neural networks as model systems for signal processing (Invited Paper) [6602-37]

C. Villard, Institute Néel, CNRS, and Univ. Joseph Fourier (France); P. O. Amblard, G. Becq, GIPSA-Lab. (France); S. Gory-Fauré, J. Brocard, CEA-Grenoble (France); S. Roth, CNRS and Univ. Joseph Fourier (France)

660218 Physical/physiological meaning of frequency modulation in brain wave with/without photostimulation [6602-40]

H. Konno, Univ. of Tsukuba (Japan); H. Chatani, Univ. of Tsukuba (Japan) and Kyushu Univ. (Japan); Y. Takahashi, Univ. of Tsukuba (Japan); A. Sakata, S. Tobimatsu, Kyushu Univ. (Japan)

\section{NEURONAL NETWORKS}

6602 1A Bayesian inferential framework for diagnostic of non-stationary systems [6602-42]

V. N. Smelyanskiy, D. G. Luchinsky, NASA Ames Research Ctr. (USA); A. Duggento,

P. V. E. McClintock, Lancaster Univ. (United Kingdom)

EVOLUTION: GENETICS

6602 1B Stochastic simulations of fatty-acid proto-cell models (Invited Paper) [6602-43]

F. Mavelli, Univ. of Bari (Italy); K. Ruiz-Mirazo, Univ. of the Basque Country (Spain)

\section{POSTER SESSION}

$66021 \mathrm{E} \quad$ Moment neuronal networks: stochastic computation in neuronal systems [6602-46]

J. Feng, Warwick Univ. (United Kingdom); Y. Deng, Hunan Univ. (China); E. Rossoni, Warwick Univ. (United Kingdom)

$66021 \mathrm{~F}$ Pattern formation in subexcitable media: interplay of noise and variability [6602-48]

E. Glatt, M. Gassel, F. Kaiser, Darmstadt Univ. of Technology (Germany)

Author Index 


\title{
Conference Committee
}

\author{
Symposium Chairs
}

M. Suhail Zubairy, Texas A\&M University (USA)

Derek Abbott, The University of Adelaide (Australia)

Conference Chair

Sergey M. Bezrukov, National Institutes of Health (USA)

Conference Cochairs

Derek Abbott, The University of Adelaide (Australia)

Nigel G. Stocks, The University of Warwick (United Kingdom)

Program Committee

R. Dean Astumian, University of Maine/Orono (USA)

Robert H. Austin, Princeton University (USA)

Franco Conti, Consiglio Nazionale delle Ricerche (Italy)

Anita Goel, Harvard University (USA)

Ewa Gudowska-Nowak, Jagellonian University (Poland)

Joseph Klafter, Tel-Aviv University (Israel)

John J. Kasianowicz, National Institute of Standards and Technology (USA)

Alexei Kornyshev, Imperial College London (United Kingdom)

Frank E. Moss, University of Missouri, St. Louis (USA)

Miguel Rubi, Universidad de Barcelona (Spain)

Lutz Schimansky-Geier, Humboldt-Universität zu Berlin (Germany)

Udo Seifert, Universität Stuttgart (Germany)

Igor M. Sokolov, Humboldt-Universität zu Berlin (Germany)

Aneta Stefanovska, Lancaster University (United Kingdom)

Christian P. Van den Broeck, Hasselt Universiteit (Belgium)

Session Chairs

Plenary Session I

Leon Cohen, Hunter College/CUNY (USA)

Single Molecules

Sergey M. Bezrukov, National Institutes of Health (USA) 
Ion Channels and Pumps

Joseph Klafter, Tel Aviv University (Israel)

Sensory Systems

Nigel G. Stocks, University of Warwick (United Kingdom)

Signal Analysis

Nigel G. Stocks, University of Warwick (United Kingdom)

Plenary Session II

János Kertész, Budapest University of Technology and Economics

(Hungary)

Networks, Cells, Population Dynamics I

Aneta Stefanovska, Lancaster University (United Kingdom)

Networks, Cells, Population Dynamics II

Aneta Stefanovska, Lancaster University (United Kingdom)

Noise Effects and Stochastic Resonance

Gleb Oshanin, Université Paris VI (France)

Debate Session-Stochastic Resonance: Trivial or Not?

Derek Abbott, The University of Adelaide (Australia)

Plenary Session III

Sergey M. Bezrukov, National Institutes of Health (USA)

Keynote Session

Ewa Gudowska-Nowak, Jagiellonian University (Poland)

Cardiovascular Systems I

Jürgen Kurths, Universität Potsdam (Germany)

Cardiovascular Systems II

Jürgen Kurths, Universität Potsdam (Germany)

Brain and Neuronal Networks

Igor M. Sokolov, Humboldt-Universität zu Berlin (Germany)

Neuronal Networks

Igor M. Sokolov, Humboldt-Universität zu Berlin (Germany)

Evolution: Genetics

Igor M. Sokolov, Humboldt-Universität zu Berlin (Germany) 